SYLWIA OKOŃ

TOMASZ OCIEPA

ALEKSANDRA NUCIA

Uniwersytet Przyrodniczy w Lublinie, Instytut Genetyki, Hodowli i Biotechnologii Roślin

Kierownik Tematu: dr hab. Sylwia Okoń prof. Uniwersytet Przyrodniczy w Lublinie, Instytut Genetyki,

Hodowli i Biotechnologii Roślin, ul. Akademicka 15, 20-950 Lublin, tel. 8144569 20,

e-mail: sylwia.okon@up.lublin.pl

Prace zostały wykonane $w$ ramach badań podstawowych na rzecz postęu biologicznego $w$ produkcji roślinnej na podstawie decyzji Ministra Rolnictwa i Rozwoju Wsi nr HOR.hn.802.9.2018, Zadanie 91.

\title{
Identyfikacja i lokalizacja markerów DNA dla wybranych genów odporności na mączniaka prawdziwego w owsie zwyczajnym oraz piramidyzacja efektywnych genów odporności w genomie owsa
}

\section{Identification and localization of DNA markers for selected powdery mildew resistance genes in oats and the pyramidization of effective resistance genes in the oat genome}

Słowa kluczowe: B. graminis f.sp. avenae, efektywność genów, markery molekularne, odporność, owies

Mączniak prawdziwy owsa powodowany jest przez Blumeria graminis DC. f.sp. avenae Em. Marchal. Choroba ta występuje powszechnie $\mathrm{w}$ wielu regionach świata powodując duże starty jakościowe i ilościowe owsa (Aung i in., 1997; Clifford, 1995; Hsam i in., 1997; Banyal i in., 2016; Xue i in., 2017). Ograniczenie strat powodowanych występowaniem mączniaka prawdziwego można osiągnąć między innymi przez wprowadzenie do uprawy odmian efektywnymi genami odporności (Feuillet i Keller, 1998). Pietrusińska i Czembor (2015) wskazują, że proces uzyskiwania odmian odpornych powinien być poprzedzony dokładną charakterystyką populacji patogenu, analizą efektywności genów odporności obecnych w odmianach uprawnych oraz opracowaniem metody pozwalającej na szybką i pewną identyfikację tych genów. 
Dlatego też celem badań realizowanych w 2018 roku w ramach zadania 91 była analiza efektywności opisanych do tej pory genów odporności na mączniaka prawdziwego w owsie oraz ich piramidyzacja. Celem projektu była również próba opracowania markerów molekularnych dla najbardziej efektywnych genów odporności na mączniaka prawdziwego w owsie.

Uzyskane wyniki potwierdziły, że najbardziej efektywne są obecnie geny Pm4 i Pm7. Niski poziom wirulencji patogenu zanotowano również względem genu Pm5. W związku $\mathrm{z}$ tym, linie zawierające te geny wykorzystano w procesie krzyżowania, w którym uzyskano szereg odpornych mieszańców. W 2018 roku przeprowadzono również próbę konwersji markerów losowych typu RAPD, SRAP i DArT w markery specyficzne oparte na PCR. Przedmiotem konwersji były zidentyfikowane w poprzednich latach markery specyficzne dla pul roślin odpornych i wrażliwych w populacjach $\operatorname{Pm} 4 \times$ Fuchs, $\operatorname{Pm} 7 \times$ Fuchs i Canyon $\times$ Fuchs.

W wyniku przeprowadzonych analiz zidentyfikowano i przekonwertowano jeden marker specyficzny dla homozygotycznych osobników z genem Pm4 w populacji Av1860 × Fuchs (Okoń i in., 2018). Zidentyfikowano również produkty specyficzne dla genu $P m 7$, jednakże próba ich konwersji nie przyniosła oczekiwanych rezultatów. Dla populacji Canyon $\times$ Fuchs zidentyfikowano tylko jeden produkt specyficznych dla pul roślin odpornych, co może wskazywać na konieczność zastosowania większej liczby starterów lub innych metod losowych do poszukiwania markerów specyficznych dla tego źródła odporności.

\section{LITERATURA}

Aung T., Thomas H., Jones T. 1977. The transfer of the gene for mildew resistance from Avena barbata (4x) into the cultivated oat $A$. sativa by an induced translocation. Euphytica 26: 623 - 632.

Banyal D. K., Sood V. K., Singh A., Mawar R. 2016. Integrated management of oat diseases in north-western Himalaya. Range Management and Agroforestry 37 (1): $84-87$.

Clifford B. C. 1995. Diseases, pest and disorders of oat. In: R. W. Welch (Ed), The Oat Crop, Chapman \& Hall, London: $252-278$.

Feuillet C., Keller B. 1998. Molecular aspects of biotic stress resistance in wheat. Proc. $9^{\text {th }}$ Int. Wheat Genet. Symp., Saskatoon, Saskatchewan, Canada, Oral Presentations. 1: 171 - 177.

Hsam S. L. K., Peters N., Paderina E. V., Felsenstein F., Oppitz K., Zeller F. J. 1997. Genetic studies of powdery mildew resistance in common oat (Avena sativa L.). I. Cultivars and breeding lines grown in Western Europe and North America. Euphytica 96: 421 - 427.

Okoń S., Ociepa T., Nucia A. 2018. Molecular identification of Pm4 powdery mildew resistant gene in oat. Notulae Botanicae Horti Agrobotanici Cluj-Napoca, 201846 (2): 350 - 355.

Pietrusińska A. Czembor J. H. 2015. Gene pyramiding - a tool commonly used in breeding programs breeding programs. Biul. IHAR 278: $3-16$.

Xue L H., Li, C. J., Zhao G. Q. 2017. First Report of Powdery Mildew Caused by Blumeria graminison Avena sativa in China. Plant Disease 101, 11: 1954. 